\title{
IMPACT OF FISCAL INTEGRATION ON EUROZONE MEMBERS (THE CASE OF SLOVAKIA)
}

\author{
Lukáš Burian \\ University of Economics in Bratislava, Slovakia \& Swiss Re. \\ Eva Muchová \\ University of Economics in Bratislava, Slovakia
}

\begin{abstract}
The eurozone is both a unique project and an unprecedented case in the history of monetary unions. It has the characteristic of a single monetary policy but with sixteen national fiscal policies. The national fiscal policy measures that are aimed at compensating for the absence of a more complete fiscal union have been orientated mainly toward domestic fiscal policy and follow domestic fiscal policy discipline. The current questions tackled by many economists within the eurozone nowadays include the following: What steps should the eurozone undergo to set out on the path of sustainability and convergence? Is deeper fiscal integration or even fiscal union the solution? The aim of the paper is to outline polemical views on fiscal integration, identify potential forms of deeper fiscal integration and simulate its impact on the integration of the Slovak economy using the computable general equilibrium (CGE) model. The collected evidence shows that either deeper fiscal integration taking the form of transfers or a common European tax would be beneficial for the eurozone Member States. Member States would thus have a tool to address unexpected developments in and asymmetric shocks to the eurozone.
\end{abstract}

Keywords: fiscal integration, CGE model, eurozone, fiscal federalism, sustainability

DOI: http://dx.doi.org/10.15549/jeecar.v8i1.551

\section{INTRODUCTION}

As membership in the eurozone monetary union has resulted in a lost opportunity for individual countries to take advantage of the stabilizing function of the flexible exchange rates and their own monetary policy, fiscal policy has become the only macroeconomic stabilization instrument they can use. However, the risk of excessive growth of public debt and budget deficits, as well as regulations at European and national levels, limits the scope for active use of the fiscal policy. A prerequisite, even a necessity, for the satisfactory functioning of a monetary union is deepening the integration towards a fiscal union.

Fiscal policy measures intended to compensate for the absence of fiscal union (for example, the Maastricht Treaty and the Stability and Growth 
Pact) have focused mainly on domestic fiscal policy discipline but have not functioned as planned, as was manifested during the 2007 crisis and recession. The importance of the existence and performance of fiscal instruments within the eurozone is also relevant in the global pandemic caused by the COVID-19, which has caused unexpected fiscal shocks.

The fiscal union project requires concrete steps that enable the deepening of fiscal integration and a movement towards political union. The basic argument for introducing a fiscal surveillance and a common fiscal framework is the fact that unsustainable fiscal policy in one Member State can destabilize the eurozone as a whole (Bénassy-Quéré et al., 2016, p.1).

This paper is aimed at presenting elements of fiscal integration and evaluating their impact on the Slovak economy through the computer general equilibrium (CGE) model. It is structured in the following parts. First is an overview of the literature that deals with deeper fiscal integration and the European Monetary Union (EMU), followed by a methodology section that introduces the methods and data utilized in the research. The subsequent section presents the analysis of the results in detail. The final part summarizes the main conclusions of our research and its limitations and provides policy recommendations for decision making.

\section{LITERATURE OVERVIEW}

During the designing phase of the euro project, it was obvious that the countries of the future monetary union would not meet the conditions of an optimal currency area (OCA), in particular the synchronization of economic cycles, price and wage flexibility, labor mobility and, especially, the option of using fiscal transfers (Pasimeni, 2014, p. 21). Monetary union was seen as a step towards deeper integration with the existence of a common currency to be later complemented by a fiscal union. The favorable effects of an expansive fiscal policy may be negated by the fact that economic agents expect an increase in interest rates introduced by the central bank due to monetary countermeasures (DeLong - Summers, 2012, p. 265). The potential effectiveness of fiscal policy is higher in the countries of the monetary union than in the economies with their own currency and their own monetary policy. As the European Central Bank (ECB) does not respond to economic developments in individual countries but instead targets at inflation throughout the monetary union, economic agents are not expecting a change in interest rates.

One of the mechanisms that can keep a country in a prolonged recession is the link between slow growth, pessimistic expectations of companies, and low willingness to invest. For this reason, fiscal stimulus to innovative sectors is even more effective, as it creates positive expectations in terms of economic growth and can free the economy from the so-called stagnation trap (Benigno \& Fornaro, 2016, p.4). On the other hand, the application of fiscal policy can be limited in the eurozone countries. The limitations stem from the measures intended to ensure the stability of the whole eurozone as unsustainable fiscal policy in one Member State can destabilize the eurozone as a whole. This leaves the Member States without an effective tool against asymmetric shocks, as their budgets are constrained by fiscal rules. The Stability and Growth Pact (SGP) that was aimed at eliminating the threat of moral hazard in individual countries' economic policies have set limits on the level of public debt and general government deficit. As eurozone countries have abandoned their own currencies, they have also lost the possibility to monetize their debts as a last resort and thus repay their liabilities at the cost of rising inflation.

Fiscal policy in unusually good or bad times should be governed by a planned independent European Fiscal Council, while the SGP should only be applied in "normal" times. Fiscal coordination is particularly needed in exceptional cases where the ECB can no longer stabilize the eurozone (Bénassy-Quéré, Ragot \& Wolff, 2016, p.1).

Because the European Financial Stability Facility and European Stability Mechanism (EFSF-ESM) is an instrument for debt crisis prevention, it does not create the possibility for fiscal transfers within the monetary union; the introduction of these instruments cannot be considered as a definite solution for the monetary union and the transition to a form of fiscal union can be considered necessary (De Grauwe, 2011, p.43). Fuest \& Peichl (2012) 
identify five potential pillars of a fiscal union, but the resulting fiscal union can, but need not, include all of them: (1) common rules, policy coordination, and surveillance; (2) a debt resolution mechanism; (3) a mechanism for providing a common debt guarantee; (4) fiscal transfers between countries; and (5) a larger EU budget and the introduction of a European tax (p.3). Fiscal rules have already been in place in the eurozone, for example, via SGP. The crisis mechanism is represented by the ESM and a joint guarantee in the form of the currently rejected Eurobonds. In our paper, we focus on the new elements that would lead to higher fiscal integration in the eurozone, to fiscal transfers and to a larger EU budget.

One of the principles of the fiscal union should be the "no bail-out" principle that must be applied in relation to individual states in the fiscal union (Stratulat \& Dhéret, 2012, p.2). The possibility of fiscal transfers in the eurozone and the EU is still very limited. Currently discussed relevant solutions can include, for example, the introduction of unemployment insurance at the level of the monetary union that should aim exclusively at providing a stabilizing function in the monetary union on the principle of an automatic stabilizer (Bénassy-Quéré - Ragot, 2015, p.12). Another possibility is the introduction of the so-called "bad times" fund that would collect contributions from Member States and provide them with resources in the event of a major negative shock (Enderlein et al., 2012, p.32). The potential growth of the budget at the level of the EU or the eurozone and the introduction of a single European tax are proposals leading to the highest form of fiscal union. At present, the EU does not have mechanisms in line with this fifth pillar. Building a fiscal union in the future will lie in deepening the first three pillars and possibly introducing the fourth and fifth pillars. When choosing from various potential forms of fiscal union, it is necessary to take into account not only their impact on individual Member States and the union's economy as a whole, but also their political permeability conditioned by public support for further integration and their trust in European institutions. The European Union and the eurozone are already characterized by several elements typical of fiscal union and other elements are outlined in The Five Presidents'
Report (Juncker et al., 2015, p.5), which states that the stabilization function of the eurozone is to be built in Europe in the second phase of the completion of the Economic and Monetary Union (EMU) in order to improve its ability to cope with macroeconomic shocks while the EMU would become more resilient.

The eurozone countries face a political compromise referring to common rules in fiscal policy, financial stability, and financial integration. This political compromise occurred in the post-crisis period but had been nonexistent in the period before it. This result can be interpreted as follows - there appear to exist two regimes in the monetary union. If confidence in the stability of the eurozone prevails, asymmetric shocks lead to the stabilization of capital flows. The need for flexibility in fiscal rules to address these asymmetric shocks is, therefore, small. Capital markets then assume a stabilizing role and capital flows represent a stabilizing factor. However, if there is mistrust in optimizing monetary union, financial markets lose confidence in sustainability and the compromise concerning fiscal rules, financial stability and financial integration becomes binding (De Grauwe \& Foresti 2016, p.13).

Current elements of the fiscal integration discussed include elements of transfers only in the scenario in which individual Member States do not meet their obligations and are not able to repay their debt. The current EU budget includes transfers under the Structural and Regional Funds as well as agricultural policy. However, these transmission mechanisms are essentially unrelated to the functioning of a monetary union, and in addition, being approximately $1 \%$ of GDP, the size of the budget is relatively small, so the scope of transfers is limited.

Fiscal equalizers usually exist in a monetary union only with a high degree of political integration, typically federations with a strong central government. There exists, however, the problem of how to separate the "guarantee" effect of a fiscal equalizer that is crucial for macroeconomic stabilization from the effect of a redistribution of wealth. A pure guarantee mechanism could find sufficient political support but introducing a significant wealth redistribution mechanism would probably face resistance. 
Another possible element of fiscal union could mean an enlarged government budget in the EU together with a European tax. Such an increased central government budget would require a significant shift in political responsibilities at the European level, which raises many questions. Given that the EU budget slightly exceeds $1 \%$ of GDP and transfer from it to the Member States is largely unrelated to macroeconomic conditions, the level of fiscal stabilization it provides would be very limited.

The stabilizing characteristics of the fiscal transfer mechanism strongly depend on the way in which the recipient economy uses transfers. Public consumption, household transfers and VAT stimulation are more effective in stabilizing macroeconomic disparities in the monetary union when asymmetric demand shocks occur, while income tax and social protection are more effective in the event of an asymmetric supply shock. In his work, Betti (2020, p.14) recommends the emergence of such fiscal transfers as he considers them as improving macroeconomic stabilization in (suboptimal) monetary unions.

As for fiscal federalism, its different definitions remain inconsistent; for example, Sorens (2008) defines the "ideal" type of fiscal federalism using four inevitable conditions: (1) political units under the central unit have autonomous decision making powers over taxes and expenditures; (2) these government units are under budgetary constraints so that no rescue rule is in line with fiscal federalism; (3) the common market is based on free trade and mobility within the Union, meaning there is the possibility of competition between government units; and (4) fiscal federalism is a rules-based institution (p.9). In addition, Bordo et al. (2011) add a fifth element, but not a condition: the common market is based on a single currency so that units below the national level are also members of the same monetary union (p.3). The requirement necessary for the success of economic integration includes political and cultural closeness. Socio-cultural closeness among the member countries of monetary integration is related to factors such as common language, cultural characteristics, similar types of education, way of life, business, and industrial practices (Yilmaz, 2017, p.51). This requirement is roughly met in the eurozone.

It is obvious, then, that fiscal federalism results in a clear loss of central government autonomy. In fact, the limited power of the central authority is a benefit (Rodden, 2005, p.56). As a result, in highly fiscally decentralized federations, it is easier to provide collective goods at the level of jurisdictions because coordination and distribution are difficult at the central level.

\section{METHODOLOGY}

In our empirical research, we have carried out a simulation using the computable general equilibrium (CGE) model. CGE models are numerical simulations based on general equilibrium principles and are designed to turn general equilibrium theory into a practical tool for policy analysis. The CGE model itself is a computer program (Gilbert et al., 2016, p.9). As a practical introduction to the structure of typical CGE models and what they can serve, see, for example, Hosoe et al. (2010) or Gilbert and Tower (2013). Dixon and Jorgenson (2013) provide an excellent overview of the latest developments in this field.

The CGE model is based on the so-called social accounting matrix (SAM), which is able to capture in detail the flows of money, goods, and services in an economy. These matrices are very detailed, and the degree of data aggregation can be changed and adjusted to research needs. For our model, we aggregate the world into 4 regions: Slovakia, the eurozone (excluding Slovakia), the rest of the EU, and the rest of the world. The reason for such aggregation is the interconnectedness of economies within the EU, and therefore the need to look at the impact of new policies and asymmetric shocks. In our model, we aggregated production in the regions into 3 sectors: agriculture, industry, and services.

The advantage of CGE models lies in their ease with which data are used. For a simple CGE model, data from national accounts for one period is sufficient. However, this advantage can also become a disadvantage: CGE models are static and thus, incorrect data selection can lead to skewed results. We use the GTAP model (Global Trade Analysis Project) and their GTAP database as a source in our research. The standard GTAP model is a multiregional, 
multisectoral, compatible general equilibrium model with perfect competition and constant economies of scale. The GTAP database is a consistent representation of the world economy for a predetermined reference year. The database is based on several data sources, for example: national input-output tables (I-O), international trade data, macroeconomic data, energy, and security data. The underlying input-output tables are heterogeneous in terms of resources, methodology, base years and sectoral details (GTAP, 2019).

Using the CGE model, we simulate asymmetric shocks for the scenario of possible future development of fiscal integration in the context of the Slovak Republic and the impact of these shocks on its economic indicators. In the GTAP model, we simulate an increase in the fiscal resources available to the eurozone by $1 \%$ of eurozone GDP. This increase in the eurozone budget represents an additional $1 \%$ to the abovementioned EU budget and the EU is redistributing the sum through its own funds. In this way, the eurozone will have a total budget of $2 \%$ (of which $1 \%$ can be transferred to Member States). The question remains how these funds can be collected. Let us consider two scenarios. The first is a possibility for countries to reduce their government spending and thus send a part of their tax revenue to the common budget of the eurozone. Tax revenues in the eurozone account for $46.5 \%$ of GDP and $40.8 \%$ of GDP in Slovakia (Eurostat, data retrieved 2018). The second option represents a new European tax that would flow directly and exclusively into the eurozone budget.

\section{RESULTS}

As we have mentioned above, transfer payments in the eurozone only work under the Structural and Regional Funds, which, however, are not linked to the stages of the economic cycle and cannot fully function as a tool to offset asymmetric shocks across the Member States. Marzinotto, Sapir, and Wolff (2011) argue that if the European Ministry of Finance took the wrong steps or if there was a need to recapitalize large banks, a stable and strong inflow of funds would be needed. These funds could be obtained, for example, from a Europe-wide tax proposed by the authors at $2 \%$ of GDP (p.7).
In the first step, we simulate the current period and situation in which reduced government spending or increased taxes would affect Slovakia and the eurozone. We simulate two situations where government spending in Slovakia is reduced by $1 \%$ of its GDP, and these funds are transferred to the eurozone that will increase government spending in the region. Subsequently, we simulate the situation that these funds are financed by the government via increasing tax revenues by $1 \%$ throughout the eurozone.

Table 1 shows the impact of the newly formed fiscal union on the monitored regions at present. As expected, we calculated a decrease in GDP in both scenarios due to the decrease in government spending by transferring the portion of existing tax revenue and lowering consumer consumption by imposing (or increasing existing) taxes. According to our calculations, in good times, it would be "less costly" to finance the eurozone budget with existing tax revenues than to create a new European tax. Reallocating existing tax revenue would result in an estimated $0.04 \%$ decrease in GDP and creating a new tax (or increasing existing taxes) would result in a $0.10 \%$ decrease. The first scenario is reflected in "Transfer of existing tax revenue." In the first scenario, the rest of the eurozone represents the recipient of these new funds, and we can estimate an increase in its GDP by $0.001 \%$. The increase is insignificant due to the low volume of transferred funds compared to the GDP of the eurozone. "New increased tax" reflects the effect of increased taxes in the Member States. These effects are represented in the second scenario in which Slovakia increases its taxes, and the new funds are transferred to the central budget. 
Table 1: Change in GDP due to introduction of fiscal union (in \%)

\begin{tabular}{|l|c|c|c|}
\hline & $\begin{array}{c}\text { Transfer of existing tax } \\
\text { revenue }\end{array}$ & $\begin{array}{c}\text { New increased } \\
\text { tax }\end{array}$ & Total effects \\
\hline Slovakia & -0.0444 & -0.0609 & -0.1053 \\
\hline Eurozone (excl. Slovakia) & 0.0001 & -0.0484 & -0.0483 \\
\hline Rest of the EU & 0.0008 & 0.0178 & 0.0186 \\
\hline Rest of the world & 0.0001 & 0.027 & 0.0272 \\
\hline
\end{tabular}

Source: Authors' calculations, RunGTAP

Table 2 documents that reducing government spending and raising the tax rate would lead to deflationary pressures. In this case, the effect of government expenditures is stronger for Slovakia than increased tax revenues (increased tax rate). The increased tax rate reduces household disposable income, thus limiting their consumption which affects aggregate demand and causes slight deflationary pressures (0.05\%). At the same time, the depletion of government spending has a similar (but larger) effect. The sum of these effects presents the situation in which a "European tax" would be introduced in the country, and these funds would be transferred from Slovakia towards the eurozone budget.

Table 2: Change in the inflation rate due to introduction of the fiscal union (in \%)

\begin{tabular}{|c|c|c|c|}
\hline & $\begin{array}{c}\text { Transfer of existing tax } \\
\text { revenue }\end{array}$ & $\begin{array}{c}\text { New increased } \\
\text { tax }\end{array}$ & Total effects \\
\hline Slovakia & -0.0971 & -0.0538 & -0.151 \\
\hline Eurozone (no Slovakia) & 0.0001 & -0.0455 & -0.0453 \\
\hline Rest of the EU & 0.0007 & 0.0168 & 0.0175 \\
\hline Rest of the world & 0.0001 & 0.0263 & 0.0264 \\
\hline
\end{tabular}

Source: Authors' calculations, RunGTAP

Household income would also be affected by the establishment of a fiscal union, as can be seen in table 3. Transferring existing tax revenue would affect households indirectly as the government decreases its spending. A decrease in government spending by $1 \%$ would affect households and simultaneously will decrease their income by $0.043 \%$. The creation of new taxes (increasing existing) would affect households' income more directly as it would decrease their disposable income (decrease by $0.106 \%$ ). The effects of the introduction of the fiscal union in the period in question are relatively low, however, indicating that the current fiscal union in the eurozone should not evoke worries about economic consequences (some moderation of economic growth is expected) but rather the political willingness to adopt these solutions should be taken into consideration.

Tables 1-3 describe how the economic situation in Slovakia will change due to the creation of a larger eurozone budget in the period in question depicting a slight decrease in the country's economic indicators.

The next step is to expose the Slovak economy to an asymmetric shock representing a $10 \%$ drop in household consumption - a demand shock. We introduce a change into the model accounting for a decrease in the variable $y p$ (regional private consumption expenditure in region $r$ ), i.e., a decrease in household consumption in the region (in our case in Slovakia) by $10 \%$. 
Table 3: Change in household income due to introduction of fiscal union (in \%)

\begin{tabular}{|l|c|c|c|}
\hline & $\begin{array}{c}\text { Transfer of existing tax } \\
\text { revenue }\end{array}$ & New increased tax & Total effects \\
\hline Slovakia & -0.043 & -0.0626 & -0.1056 \\
\hline Eurozone (no Slovakia) & 0.0002 & -0.0498 & -0.0496 \\
\hline Rest of the EU & 0.0009 & 0.0182 & 0.0191 \\
\hline Rest of the world & 0.0001 & 0.0273 & 0.0275 \\
\hline
\end{tabular}

Source: Authors' calculations, RunGTAP

Given that this is a significant shock, the eurozone is responding with a fiscal transfer to Slovakia, thus increasing government spending by $3 \%$ of its GDP, and the eurozone will reduce its government spending by this amount as well. Table 4 shows the impact of the shock alone (marked as "Demand shock" column) on GDP reaching more than $2 \%$, but the fiscal transfer from the common budget helps to mitigate the effects of this shock without Slovakia having to become over-indebted. The transfer of funds from the central budget would positively offset the shock by $0.409 \%$. We estimate that the impact of new increased taxes would decrease Slovakia's GDP by $0.0376 \%$, which is lower than in the period in question (Table 1). As we have mentioned above, the reason lies in the fact that a new European tax would be linked directly to the economic cycle.

Table 4: Impact of an asymmetric demand shock on GDP (in \%)

\begin{tabular}{|l|c|c|c|c|}
\hline & $\begin{array}{c}\text { Transfer of existing } \\
\text { tax revenue }\end{array}$ & $\begin{array}{c}\text { New } \\
\text { increased tax }\end{array}$ & $\begin{array}{c}\text { Demand } \\
\text { shock }\end{array}$ & $\begin{array}{c}\text { Total } \\
\text { effects }\end{array}$ \\
\hline Slovakia & 0.409 & -0.0376 & -2.1126 & -1.7413 \\
\hline Eurozone (no Slovakia) & -0.0006 & -0.0258 & 0.0012 & -0.0252 \\
\hline Rest of the EU & -0.0012 & 0.0182 & -0.0035 & 0.0135 \\
\hline Rest of the world & -0.0008 & 0.0213 & 0.0031 & 0.0236 \\
\hline
\end{tabular}

Source: Authors' calculations, RunGTAP

Similarly, fiscal transfer helps to ease deflationary pressures and the decline in household consumption, as shown in Tables 5 and 6 . At the same time, we can observe that the effect of increased taxes on the inflation rate and household income is lower than in the period preceding the asymmetric shock.

Table 5: Impact of an asymmetric demand shock on inflation rate (in \%)

\begin{tabular}{|l|c|c|c|c|}
\hline & $\begin{array}{c}\text { Transfer of existing } \\
\text { tax revenue }\end{array}$ & $\begin{array}{c}\text { New increased } \\
\text { tax }\end{array}$ & $\begin{array}{c}\text { Demand } \\
\text { shock }\end{array}$ & Total effects \\
\hline Slovakia & 0.5198 & -0.0332 & -1.7484 & -1.2618 \\
\hline Eurozone (no Slovakia) & -0.0006 & -0.0253 & 0.0015 & -0.0244 \\
\hline Rest of the EU & -0.0011 & 0.019 & -0.0042 & 0.0137 \\
\hline Rest of the world & -0.0007 & 0.021 & 0.003 & 0.0232 \\
\hline
\end{tabular}

Source: Authors' calculations, RunGTAP 
The demand shock would cause $1.7484 \%$ deflation in the Slovak economy, but this effect will be partially offset by transferring the funds from the central budget by $0.5198 \%$, and with new increased taxes, the total effect of an asymmetric demand shock on the Slovak economy would lead to deflationary pressure of $1.2618 \%$.

Table 6: Change in household income due to asymmetric demand shock (in \%)

\begin{tabular}{|l|c|c|c|c|}
\hline & $\begin{array}{c}\text { Transfer of existing } \\
\text { tax revenue }\end{array}$ & $\begin{array}{c}\text { New } \\
\text { increased tax }\end{array}$ & $\begin{array}{c}\text { Demand } \\
\text { shock }\end{array}$ & Total effects \\
\hline Slovakia & 0,4193 & $-0,0384$ & $-2,2227$ & $-1,8418$ \\
\hline Eurozone (no Slovakia) & $-0,0006$ & $-0,0263$ & 0,0014 & $-0,0256$ \\
\hline Rest of the EU & $-0,0015$ & 0,0181 & $-0,0027$ & 0,0139 \\
\hline Rest of the world & $-0,0008$ & 0,0214 & 0,0032 & 0,0238 \\
\hline
\end{tabular}

Source: Authors' calculations, RunGTAP

Household income would also suffer from negative demand shock, decreasing by more than $2.2 \%$. Transferring funds from the central budget due to the asymmetric demand shock would cause an increase in household income by $0.4193 \%$ because of increased government spending. The total effect of the shock on household income would decrease by $1.8418 \%$. One question raised in this context is how effectively the government would allocate new funds.

Based on our findings, we can conclude that deeper fiscal integration in the form of transfers or a common European tax would be beneficial for eurozone Member States. The Member States would have a tool to defend themselves against unexpected situations and asymmetric shocks. The "price" for the implementation of such an instrument would be a slight slowdown in economic growth in the "good times."

The creation of a common budget is desirable for the sustainability of the eurozone and the European Union. In the future, these measures should ensure that the eurozone can cope with the unexpected challenges that might arise.

\section{CONCLUSIONS AND RECOMMENDATIONS}

During the preparation of the monetary union in Europe, opinions emerged that the EMU could only be successful in the long run if a system of automatic transfer payments between the countries, so-called fiscal federalism, is in place. The emergence of the eurozone has pushed aside the issue of fiscal union, but the previous economic and current pandemic-related crises have reopened the debate. Of the three classic functions of fiscal policy - the provision of public goods, redistribution, and stabilization - only the latter provides an unambiguous rationale for fiscal policy at the eurozone level. Unsustainable fiscal policy in one Member State can destabilize the eurozone as a whole, and national policies can have a direct or indirect effect on demandside inflation at the transnational level. An "everyone for himself" policy is ineffective in this case, but coordination is challenging as it involves 19 national budgetary processes and a common central bank. (Bénassy-Quéré, Ragot, and Wolff, 2016, p.1)

Based on our analysis using the CGE model, we can assess that deeper fiscal integration in the form of transfers, or a common European tax, would be beneficial for eurozone Member States. The Member States would have a tool to defend themselves against unexpected situations and asymmetric shocks. The "price" for the implementation of such an instrument would be a slight slowdown in economic growth in "good times." In the case of Slovakia, the slowdown effect would be reflected in a decrease of its GDP (by 1\%), deflationary pressure, and lower household income in "good times" (as shown in Tables 1-3). On the other hand, Slovakia would gain a countermeasure for asymmetric shocks. As shown in tables 4-6, the effect of a demand shock is decreased by receiving support in the form of transfers from the central budget. The 
emergence of fiscal federalism should thus prevent budget deficits leading to unsustainable debt dynamics that are very difficult to stop and stabilize.

Based on our findings, we can recommend that Slovakia and the eurozone should focus on deepening fiscal integration. The creation of a common budget of adequate size and linked to economic cycles is desirable for the sustainability of the eurozone and the European Union. Therefore, our proposal is to create a larger eurozone budget of at least 1\% of Member States' GDP. We have shown in the model that such an increase will not have major negative effects on the Member States, but these measures could ensure that the eurozone can cope with unexpected future challenges as well as the existing challenges it faces at present (such as the global COVID-19 pandemic).

In the future, the GTAP model can be improved in several ways. In continued research, we plan to examine whether the budgetary authority can also manage a surplus and, if necessary, invest and use these surpluses for worse times. Another area of our research may include the analysis of the impact that creation of fiscal union on various sectors of the eurozone economy. We have not examined in our GTAP model individual sectors, instead focusing exclusively on the macroeconomic impact of the creation of a fiscal union. It therefore will be possible in future analyses to use a different degree of aggregation and to monitor the effects of asymmetric shocks, for example, on individual sectors or individual households based on their income.

\section{ACKNOWLEDGEMENTS}

This paper was supported by the Grant Agency KEGA no. 035EU-4/2020 and the Grant Agency VEGA no. $1 / 0356 / 19$.

\section{REFERENCES}

Bénassy-Quéré, A., Ragot, X., Wolff, G. (2016). Which Fiscal Union for the eurozone? Notes du conseil danalyse economique, (2), 1-12.

Bénassy-Quéré, A., Ragot, X. (2015). A policy mix for the eurozone. Notes du conseil danalyse economique, (2), 1-12.

Benigno, G., Fornaro, L. (2016). Stagnation Traps, CEP Discussion Paper No 1405 February 2016.

Betti, T. (2020). Fiscal transfers in a two-level fiscal framework: stabilizing properties according to the fiscal instrument (No. 2020-11). Bureau d'Economie Théorique et Appliquée, UDS, Strasbourg.

Bordo, M., Markiewicz, A., Jonung, L. (2011). A Fiscal Union for the Euro: Some Lessons from History (Vol. 17380). NEBR Working Paper Series.

Burian, L. (2020). Further Fiscal Integration in eurozone. Edamba 2019: International Scientific Conference for Doctoral Students and Post-Doctoral Scholars, 62-69.

DeLong, J. B., Summers, L. H., Feldstein, M., Ramey, V. A. (2012). Fiscal policy in a depressed economy [with comments and discussion]. Brookings Papers on Economic Activity, 233-297.

De Grauwe, P., Foresti, P. (2016). Fiscal rules, financial stability, and optimal currency areas. Economics Letters, 145, 278-281.

De Grauwe, P. (2011). Managing a fragile Eurozone. In CESifo Forum (Vol. 12, No. 2, pp. 40-45). München: ifo Institut-LeibnizInstitut für Wirtschaftsforschung an der Universität München.

Dixon, P. B., Jorgenson, D. (Eds.). (2012). Handbook of computable general equilibrium modeling (Vol. 1). Newnes.

Enderlein, H., Bofinger, P., Boone, L., De Grauwe, P., Piris, J. C., Pisani-Ferry, J., Vitorino, A. (2012). Completing the Euro: A road map towards fiscal union in Europe. Report of the "Tommaso Padoa-Schioppa Group," Notre Europe, (92).

Fuest, C., Peichl, A. (2012). European Fiscal Union: What Is It? Does It Work? And Are There Really'No Alternatives'? In CESifo Forum (Vol. 13, No. 1, pp. 3-9). München: ifo 
Institut-Leibniz-Institut für Wirtschaftsforschung an der Universität München.

Gilbert, J., Furusawa, T., Scollay, R. (2016). The economic impact of Trans-Pacific partnership: What have we learned from CGE simulation?

Gilbert, J., Tower, E. (2012). Introduction to numerical simulation for trade theory and policy. World Scientific Publishing Company.

GTAP (2019). GTAP 10 Data Base. In VOX

Hosoe, N., Gasawa, K., Hashimoto, H. (2010). Textbook of computable general equilibrium modeling: programming and simulations. Springer.

Juncker, J. C., Tusk, D., Dijsselbloem, J., Draghi, M., Schulz, M. (2015). Completing Europe's economic and monetary union.

Marzinotto, B., Sapir, A., \& Wolff, G. B. (2011). What kind of fiscal union? Bruegel Policy Brief 2011/06, November 2011.

Pasimeni, P. (2014). An optimum currency crisis. The European Journal of Comparative Economics, 11(2), 173-204.

Rodden, J. (2006). Hamilton's paradox: the promise and peril of fiscal federalism. Cambridge University Press.

Sorens, J. (2008). Fiscal federalism: A return to theory and measurement. Retrieved, 27, 2017.

Stratulat, C., Dhéret, C. (2012). A tale of modernday capitalism and democracy: in view of the European protests. EPC Policy Brief, Brussels: European Policy Centre.

YILMAZ, S. (2017). Eurasian Economic Union: A Regional Economic Hegemony Initiative. Journal of Eastern European and Central Asian Research (JEECAR), 4(2), 15. https://doi.org/10.15549/jeecar.v4i2.166

\section{ABOUT THE AUTHORS}

Lukáš Burian, email: lukas.burian@euba.sk

Dr. Lukáš Burian is an Economic Reporting Analyst at Swiss Re. His research is focused on the fiscal integration in Europe and macroeconomics.

Dr. Eva Muchová is the Professor at the Department of Economics, the University of Economics in Bratislava. Her research is focused on the European integration, international economics, and methodology of teaching economics. 